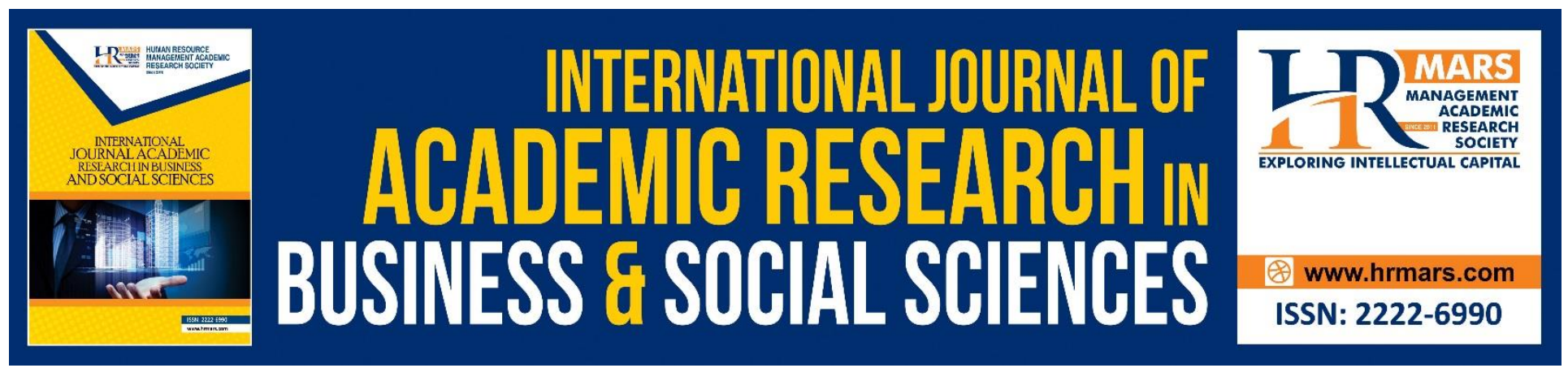

\title{
Elements of Integrity within Muslim Individuals According to the Thought of al-Ghazali
}

Mohd Hasrul Shuhari, Mohd Fauzi Hamat, Mohd Sani Ismail, Yusrina Jaffar, Mohd Fadzhil Mustafa \& Mohd Shaifulbahri Abdullah

To Link this Article: http://dx.doi.org/10.6007/IJARBSS/v8-i10/4732 ～DOI: 10.6007/IJARBSS/v8-i10/4732

Received: 17 Sept 2018, Revised: 11 Oct 2018, Accepted: 16 Oct 2018

Published Online: 31 October 2018

In-Text Citation: (Shuhari et al., 2018)

To Cite this Article: Shuhari, M. H., Hamat, M. F., Ismail, M. S., Jaffar, Y., Mustafa, M. F., \& Abdullah, M. S. (2018). Elements of Integrity within Muslim Individuals According to the Thought of al-Ghazali. International Journal of Academic Research in Business and Social Sciences, 8(10), 270-278.

Copyright: (C) 2018 The Author(s)

Published by Human Resource Management Academic Research Society (www.hrmars.com)

This article is published under the Creative Commons Attribution (CC BY 4.0) license. Anyone may reproduce, distribute, translate and create derivative works of this article (for both commercial and non-commercial purposes), subject to full attribution to the original publication and authors. The full terms of this license may be seen

at: http://creativecommons.org/licences/by/4.0/legalcode

Vol. 8, No. 10, 2018, Pg. 270 - 278

http://hrmars.com/index.php/pages/detail/IJARBSS

JOURNAL HOMEPAGE

Full Terms \& Conditions of access and use can be found at http://hrmars.com/index.php/pages/detail/publication-ethics 


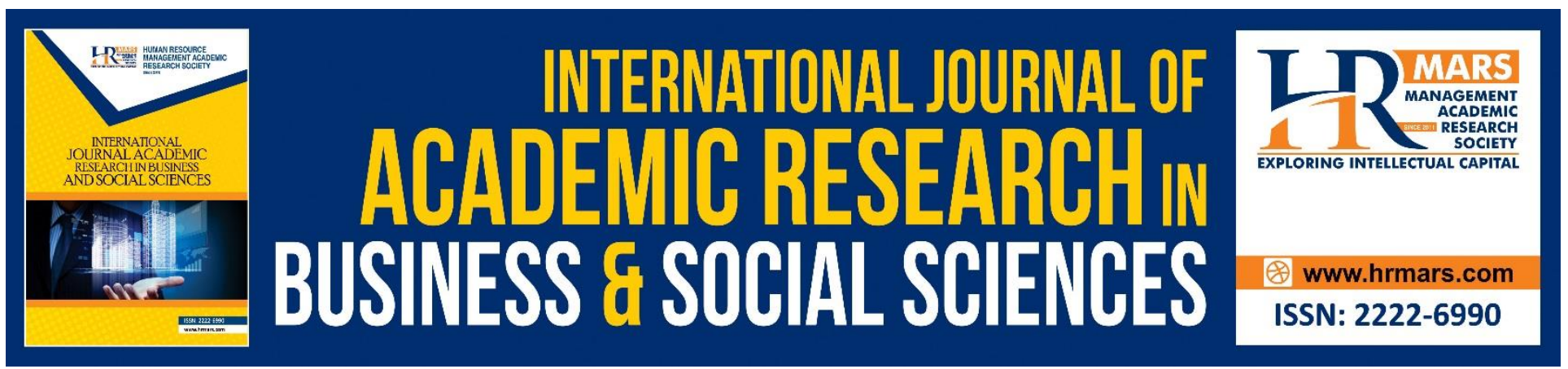

\title{
Elements of Integrity within Muslim Individuals According to the Thought of al-Ghazali
}

\author{
Mohd Hasrul Shuhari ${ }^{1}$, Mohd Fauzi Hamat ${ }^{2}$, Mohd Sani Ismail ${ }^{1}$, \\ Yusrina Jaffar ${ }^{3}$, Mohd Fadzhil Mustafa ${ }^{1}$ \& Mohd Shaifulbahri \\ Abdullah ${ }^{1}$ \\ ${ }^{1}$ Faculty of Islamic Contemporary Studies (FKI), University of Sultan Zainal Abidin (UniSZA), Gong \\ Badak Campus, 21300 Kuala Nerus, Terengganu, Malaysia, hasrulshuhari@unisza.edu.my \\ ${ }^{2}$ Department of Aqidah and Islamic Thought, Academy of Islamic Studies, University of Malaya \\ 50603, Kuala Lumpur, Malaysia \\ ${ }^{3}$ Sekolah Menengah Kebangsaan, Seri Pengkalan Alor Gajah Melaka, Malaysia
}

\begin{abstract}
Integrity is one of the moral qualities of human that need to be translated into everyday life particularly by Muslim individuals. This attribute will motivate a person to avoid something that could cause him to be considered as an individual without integrity. The characteristics of a person without integrity include deceptive, treacherous, deviant, corruption, money politics and the like. These characteristics could be avoided successfully if the individual tries to adorn himself with elements of integrity. Such elements to be considered are al-Sidq (truthfulness), al-Amanah (fulfilling trusts), and al-Mas'uliyyah (responsible). These elements will be elaborated based on the thought of al-Ghazali (d. $505 \mathrm{H}$ ) through a selection of his book. This article concludes that these elements are able to establish the quality of integrity within Muslim individuals.
\end{abstract}

Keywords: Integrity, Muslim Individuals, Al-Ghazali, Morals.

\section{Introduction: Al-Ghazali}

Abu Hamid Muhammad ibn Muhammad ibn Muhammad ibn Ahmad al-Tusi al-Shafi i and was born on the $450 \mathrm{H}$ in Tus. Al-Ghazali, the son of Imam al-Haramayn al-Juwayni, mastered knowledge in various fields, thus called as an Islamic argumentist (hujjat al-Islam). He had written reports in various fields of study and his councils were attended by famous scholars. This famous scholar practiced alShafi $i$ in and stood with al-Asha'irah. According to Yusuf al-Qaradawi, his mastery in various fields of knowledge and honor given to him, hujjah al-Islam, encourages the historians (muarrikhin) and hadith scholars (muhaddithin) to agree without doubt that he is the mujaddid (reformer) in that century (fifth century). Al-Ghazali died at the age of 55 years on Monday, 14th Jamadil Akhir $505 \mathrm{H}$ 
INTERNATIONAL JOURNAL OF ACADEMIC RESEARCH IN BUSINESS AND SOCIAL SCIENCES

Vol. 8, No. 10, Oct. 2018, E-ISSN: 2222-6990 @ 2018 HRMARS

and was buried in Tus (IbnKathir, 1998; al-'Imad, 1989; al-Madkur, 2009; al-Qaradawi, 1994; Fauzi and Hasrul, 2017).

\section{The Suitability Of Al-Ghazali's Thinking}

The thought of al-Ghazali is appropriate to be learnt by Muslim individuals, especially the majority of the Muslim community in Malaysia. This is because the Muslim community in Malaysia has been exposed widely to the influence of al-Ghazali's thought through the seminars and scripture councils. Al-Ghazali's teachings have been commonly taught in musolla, mosques and pondok-styled institution by the speakers and teachers who teach his books. So, they are easy to accept and practice al-Ghazali's way of thinking. There is an educational-chain linking the ulama in the Malaya with alGhazali. Ahmad al-Qushashi and Ibrahim al-Kurani were among the scholars who linked al-Ghazali's thinking to the Malay scholars back at the days. For example, among the Malay scholars who studied with al-Kurani was Shaykh Abd al-Ra'uf Singkel. Shaykh Muhammad Yasin al-Fadani also lists the books of al-Ghazali such as Ihya' 'Ulum al-Din, Minhaj al-'Abidin, Bidayah al-Hidayah and al-Hikmah fi Makhluqat Allah that were accepted through his teacher, Shaykh Muhammad Ali al-Maliki that is linked to Shaykh Ahmad al-Ramli based on sanad al-Kurani to al-Ghazali (Abdullah, 2004; Fauzi and Hasrul, 2017).

In 1778M, Shaykh `Abd al-Samad al-Falimbani translated and described the book Bidayah alHidayah in his work entitled Hidayah al-Salikin (Ahmad Fathy al-Fatani, 2002). Raja Ali Haji also contributed in spreading al-Ghazali's thinking, especially those that contained in Ihya' 'Ulum al-Din, Minhaj al-'Aididin and Bidayah al-Hidayah into the Malay world as for example through his poetic masterpiece entitled Gurindam Dua Belas (Watson, 1979; Sham, 2004). The book Bidayah al-Hidayah was also lectured by a Malay scholar named Muhammad al-Nawawi al-Jawi al-Makki in his work, Maraqi al- 'Ubudiyyah (al-Ghazali, 1985). According to Hamka (1977), al-Ghazali's thought through his book, Ihya' 'Ulum al-Din greatly influenced the Malay community. He acknowledged that his work entitled Tasawwuf Moden (1939M), the Lembaga Hidup (1940M) and the Lembaga Budi (1940M) was influenced by al-Ghazali's thinking through Ihya' 'Ulum al-Din, Minhaj al-'Abidin and Bidayah alHidayah (Sham, 2004; Fauzi andHas rul, 2017). After understanding the reality of the Malaysian society, especially the Muslims who are already familiar with al-Ghazali's thinking, it is important that al-Ghazali's ideas are to be spread among Malaysians more systematically (Fauzi and Hasrul, 2017).

\section{Integrity from Islamic Perspective}

The word 'integrity' was taken from a Latin word, integer which means entire or a whole or untouched. It also carries the meaning of intact, sound, true or reliable (Zaidi and Sani, 2011; Mustafar, 2009). Integrity means the quality of being honest and having strong moral principles or the quality of being honest and upright. In summary, integrity is translated as honesty (New Oxford, 2004; Kamus, 2002). According to al-Mawrid dictionary, translating the English word 'integrity' to the Arabic language would give the meaning of salamah (far from shame and disease), kamal (perfect), istiqamah (moral virtue), amanah (sincere; opposite to treacherous, one example is keeping promises) and al-tamamiyyah (the original word is tamam which means perfection) (Ba'albaki, 1991; Mujamma', 2005; al-Munjid, 1988). 
Integrity also means something against corruption. If corruption is defined as the misuse of entrusted power for personal and political purposes, then integrity means the use of public power for a purpose which is officially confirmed and justified by the public (Jeremy, 2007). In the Malay language, integrity refers to individual character. Based on Kamus Dwibahasa (2008), the word means honesty, uprightness, sincerity, perfection and completeness (Wan Mohamad, 2009). Integrity means honesty in the Kamus Dewan (2007). It also refers to a state of perfection and intact or completeness (Zulkifli, 2009; Zulkifli, 2008). From the Islamic perspective, integrity can be attributed directly and in parallel with the attributes of trust, honesty, faith, strong belief, powerful character and noble manners. For believers, integrity at a high degree in the sight of God is piety that is doing what he was told and stay away from things that are prohibited (Ali, 2009).

\section{Elements of Integrity within Muslim Individuals}

Al-Ghazali uses a number of terms that can be associated with the concept of integrity. The terms are al-sidq, al-amanah and al-mas'uliyyah. These terms can also be defined as elements which are able to build integrity within Muslim individuals. The explanations are as follow:

\section{Al-Sidq}

Al-Sidq originally referred to the strength of something like words and so on. Strength here is meant to be the strength of reliability and truth of something. The opposite of al-sidq is al-kidhb as mentioned by Sayyidina Abu Bakr al-Siddiq, in which the essence of sidq is amanah, while the essence of kidhb is khiyanah (al-Hakim, 1981; Zaidi and Sani, 2011). Al-Sidq is also related to sincerity as explained by al-Jurjani (1985) that al-sidq is the origin and the beginning, while al-ikhlas is a branch of al-sidq. According to al-Kashani (2007), a person who has the perfect al-sidq is those who has perfect tasdeeq (acceptance) of all and everything brought by the prophet Muhammad S.A.W, be it his knowledge, word and deed.

Al-Ghazali describes al-sidq through the verses of the Quran and Hadith, which include (alGhazali, t.t.):

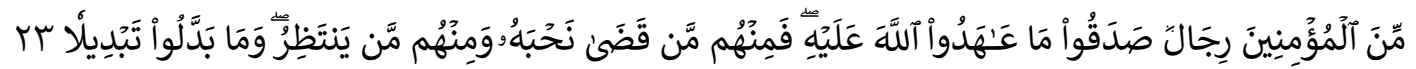

Translation: "Among the believers are men who have been true to their convenant with Allah: of them some have completed their vow through sarificing their lives, and some others are waiting for it, and have not changed their determination in the least.'

(al-Ahzab 33: 23)

Words of the Prophet S.A.W:

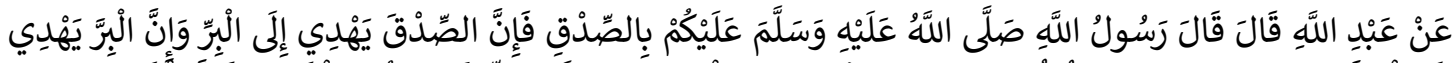

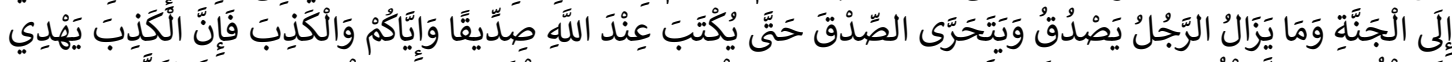

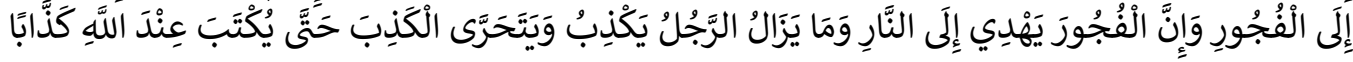


INTERNATIONAL JOURNAL OF ACADEMIC RESEARCH IN BUSINESS AND SOCIAL SCIENCES Vol. 8, No. 10, Oct. 2018, E-ISSN: 2222-6990 @ 2018 HRMARS

Translation: Abdullah reported: Rasulullah S.A.W said, "You must be truthful, for truthfulness leads to righteousness and righteousness leads to Paradise. A man will keep speaking the truth and striving to speak the truth unti he will be recordedwith Allah as a siddiq (speaker of the truth). Beware of telling lies, for lying leads to immorality and immorality leads to Hellfire. A man will keep telling lies and striving to tell lies until he is recorded with Allah as a liar." (Muslim, 2000)

According to al-Ghazali (t.t.), al-sidq utterance is employed in six different meanings, and whoever succeed to possess all of them deserve to be called al-siddiq i.e al-sidq which has the mubalaghah (hyperbole) meaning. The first meaning is al-sidq fi al-qawl (in words) referring to the news mentioned either in connection with past or future as well as keeping or betraying promises. Someone who confesses that he is the servant of Allah S.W.T but submits to his lust is hence a liar. The second meaning is al-sidq fi al-niyyah wa al-iradah (the intent and the will), which refers to the sincerity in which every motion and rest is driven by Allah S.W.T. If it is driven by selfish motive which is not for Allah's sake, then it is a lie. Even though his words are true but is still considered a lie because of the wrong intent of his heart which resembles a hypocrite.

The third meaning is al-sidq fi al- 'azm (in determination) i.e. the strong determination of doing something good without any other tendency, doubts and weaknesses in doing it. It is a strong determination that was set before the practice. Even if he might get killed in a war, the determination remains firmly to sacrifice for war. The fourth meaning is al-sidq fi al-wafa 'bi al- 'azm (in keeping promises with determination), in which Allah S.W.T takes a person determination as a promise. If he reach the determination then it is true and if otherwise then it is a lie. Al-sidq in this section is heavier than the third. This is because, sometimes human set their determination with nonchalance which lead them to be dominated by lust and thus weakened the determination (al-Ghazali, t.t.).

The fifth meaning is al-sida fi al- 'amal (in practice) which refers to a person who strives earnestly to apparently not showing what is in his being which is not his attribute. Instead his practices conform outwardly as in his being. For example, a person performs a khusyu' (engrossed, humble) prayer and he does not do it to be seen by others. Although he is true for not being riy $a^{\prime}$ (show off, seeking admiration) yet is still not al-sidq in practice because the inner is in fact does not as khusyuk as in appearance. The sixth meaning is al-sidq tahqiq fi maqamat al-din (the verification of religious station) where it is of the highest and most noble as al-sidq on al-khawf (fear), al-raja' (hope), al-ta'zim (honour), al-zuhd (ascetic), al-rida (contentment), al-tawakkal (confidence), al-hubb (love) and others. One should have these attributes in his whole being despite not meeting all those attributes. Someone who fears Allah S.W.T is not necessarily really scared of Him relative to his fear to face a cruel king or robber (al-Ghazali, t.t.).

The conclusion is that al-sidq refers to six definitions which include the word, intent and will, determination and its fulfillment, balance and preference between spiritual and physical practices, and religious maqam (station, rank). It emphasizes the separation of both internal and external self from the domination of lust, very committed to obey Allah S.W.T, parallel spiritual and physical 
INTERNATIONAL JOURNAL OF ACADEMIC RESEARCH IN BUSINESS AND SOCIAL SCIENCES Vol. 8, No. 10, Oct. 2018, E-ISSN: 2222-6990 @ 2018 HRMARS

practices that completes each other according to the command of Allah S.W.T as well as striving to adorn themselves with admirable qualities in the real sense even if it is not possible to achieve all the qualities to reach the highest and perfect maqam (station or rank). These elements will help the Muslim individuals for example by not committing fraud. This is because, al-sidq fi al-qawl (truthful in words) encourage him to always speak the truth.

\section{Al-Amanah and Al-Mas'uliyyah}

Al-Amanah and al-mas'uliyyah intertwined because a given trust should be undertaken with full responsible. If a person fails to preserve the trust then he will be liable to be repaid in kind. According to al-Ghazali, the word amanah was derived from the word al-amn because it refers to a person who is free from the commission of breach of his own rights. While khiyanah, taken from the word alkhawn, which means reduce which refers to someone betraying the other, he has reduced or lessen the rights of others (al-Hakim, 1981; al-Ghazali, 1990). The Quranic verse that mentions about alamanah is as Allah says:

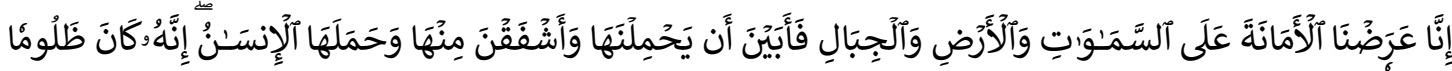

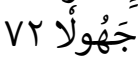

Translation: "Indeed, we offered the Trust to the heavens and the earth and the mountains, and they declined to bear it and feared it; but man [undertook to] bear it. Indeed, he was unjust and ignorant."

(al-Ahzab 33: 72)

This verse explains the rejection of al-amanah given by Allah SWT by heavens, the earth and the mountains. They are all concerned with their inability to take on al-amanah or fear of causing khianat (treacherous) that cause them to be punished later. Al-Amanah in this verse refers to the practice of devotion and religious obligation which also have implications for reward and sin. AlGhazali (1990) quoted the opinion of al-Qurtubi which is also the opinion of jumhur ulama (majority of muslim scholars) that al-amanah covers all wazaif al-din (religious duty). Al-Ghazali (1990) also links al-amanah with iman (faith), which will not be perfect for those without al-amanah. This is because, al-amanah was also derived from the word al-iman. Hence, whoever preserves the trust granted by Allah, Allah will then preserve his iman (faith) (al-Hakim, 1981). The difference between human, the heaven, the earth and the mountains is that humans are willing to take al-amanah i.e. al$m a$ 'rifah and al-tawhid, while the others are not able to do it (al-Ghazali, t.t.).

Defending and preserving Al-Amanah properly are the nature of the angels, the prophets and messengers a.s and the people of taqwa (piety, fearing Allah). Al-Amanah for leaders is to perform $d a^{\prime} w a h$ (educating and preaching of Islam) in order to chasten the unjust and protect the rights of Muslims and orphans. An ulama (muslim scholars) preserves al-amanah by teaching the knowledge of Islam to society. Parents are entrusted to keep their al-amanah by providing education for their children.24 In fact, al-amanah for an imam who led a congregational prayer is someone who is spiritually free from fasiq (disobedient to Allah), major sin and does not sustaining the minor sins. This is because the imam is like delegate that helps others, thus surely he should be one of the best in the community (Al-Ghazali, 1990). Allah S.W.T says in al-Quran: 


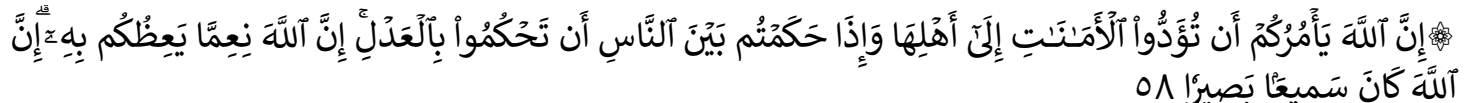

Translation: Verily! Allah commands that you should render back the trusts to those, to whom they are due; and that when you judge between men, you judge with justice. Verily, how excellent is the teaching which He (Allah) gives you! Truly, Allah is Ever All-Hearer, All-Seer.

(al-Nisa' 4: 58)

The grantor of al-amanah will also be held responsible, in which al-Ghazali (t.t.) tells us the story of a Bedouin man who rebuked a sultan. He informed the sultan that there are those people around the sultan who are more concerned about the world. So, he advised the sultan to be careful when granting al-amanah to them in doing something because the sultan will be held responsible for his nonchalant nature in granting al-amanah. Al-Ghazali (t.t.) also presents a hadith which shows that every man is responsible for al-amanah executed by them:

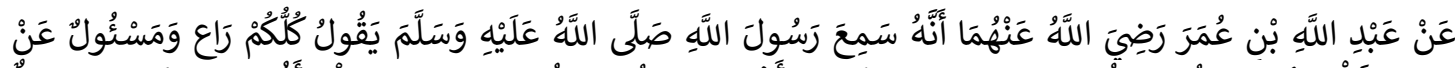

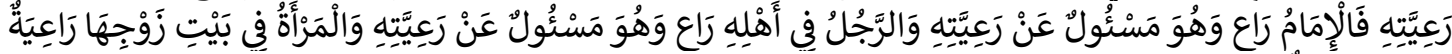

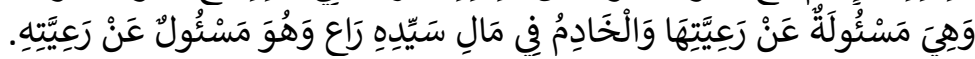

Ibn 'Umar said, I heard the Messenger of Allah S.A.W says: "All of you are shepherds and each of you is responsible for his flock. An Imam is a shepherd and he is responsible for those in his care. A man is a shepherd in respect of his family and is responsible for those in his care. The woman is a shepherd in respect of her husband's house and is responsible for those in her care. The servant is a shepherd in respect of his master's property and is responsible for what is in his care. All of you are shepherds and each of you is responsible for his flock." (Al-Bukhari, 2000).

The conclusion is that al-amanah and al-mas'uliyyah refers to something that is granted to a person to be performed or preserved and that person will be held responsible for errors or treacherous. In the event of such, then a person entrusted with al-amanah will be held accountable and must face the punishment of his guilt accordingly. Al-amanah here is meant to be all duties assigned by Allah S.W.T to mankind, and they will be tortured for failure to obey. Those who succeed will receive the reward, not to mention that al-amanah is highly correlated with al-iman in which if taken care, then their al-iman will be taken care of. Both of these elements will motivate a person not to commit treachery and the like. Eventually, he deserves to be a Muslim individual of integrity.

\section{Conclusion}

The thought of al-Ghazali is appropriate to be learnt by Muslim individuals in Malaysia because they has been exposed widely to the influence of al-Ghazali's thought. Muslim individuals with integrity are individuals who possess the elements of integrity within themselves. Those elements are $a l$-sidq (truthfulness), al-amanah (fulfilling trusts), and al-mas'uliyyah (responsible). The element of al-sidq covers the word, intent, will, determination and its realisation, balance or priority between the 
INTERNATIONAL JOURNAL OF ACADEMIC RESEARCH IN BUSINESS AND SOCIAL SCIENCES Vol. 8, No. 10, Oct. 2018, E-ISSN: 2222-6990 @ 2018 HRMARS

spiritual and physical practices, and noble qualities. The elements of al-amanah and al-mas'uliyyah refer to something that are granted to a person to be performed or properly cared for and he will be held responsible for errors or treacherous. These elements will help individuals by preventing them from doing something against the attributes of integrity such as treacherous and the like. Eventually, that person deserves to be a Muslim individual of integrity.

\section{Acknowledgement}

This paper is founded on the research project of the Fundamental Research Grant Scheme FRGS/1/2017/SSI03/UNISZA/03/1 (RR233). Rekabentuk Model Pembinaan Karakter 'Ibad al-Rahman Berdasarkan Pengalaman Pendidikan al-Ghazali, al-Shafie, Ibn Sina dan Muhammad al-Fatih. Special appreciation is owed to Ministry of Higher Education Malaysia (MOHE) and Universiti Sultan Zainal Abidin (UniSZA) for sponsoring and supporting this research.

\section{Corresponding Author}

Mohd Hasrul bin Shuhari

Centre for Usuluddin Studies, Faculty of Islamic Contemporary Studies (FKI), University of Sultan Zainal Abidin (UniSZA), Gong Badak Campus, 21300 Kuala Nerus, Terengganu, Malaysia.

Tel: 09-6688163. E-mail: hasrulshuhari@unisza.edu.my

\section{References}

Al-Madkur, A. H. (2009), "Ittijahat al-Muslimin Nahwa al-Tasawwuf”, fi Ishraf Mahmud Hamdi Zaqzuq, Mawsu ah al-Tasawwuf al-Islami, Kaherah: Dar al-Kutub al-Misriyyah.

Al-Hajjaj, A. H. M. (2000), Sahih Muslim, Kitab al-Birr wa al-Silah wa al-Adab, Bab Qubh al-Kadhibi wa Husn al-Sidq wa Fadlihi, hadith no. : 6639, in Salih ibn `Abd al-`Aziz ibn Muhammad ibn Ibrahim 'Ali Sheikh (ed.), Mawsu 'ah al-Hadith al-Sharif al-Kutub al-Sittah, c. 3, Riyad: Dar al-Salam li al-Nashr wa al-Tawzi'.

Al-Bukhari, M. I. (2000), Sahih al-Bukhari: Kitab fi al-Istiqrad wa Ada' al-Duyun wa al-Hajr wa alTaflis, Bab al-'Abd Ra`in fi Mali Sayyidihi wa la Ya`malu illa Biidhnihi, hadith no 2409, in Salih ibn 'Abd al-'Aziz ibn Muhammad ibn Ibrahim `Ali Sheikh (ed.), Mawsu'ah al-Hadith al-Sharif al-Kutub alSittah, c. 3, Riyad: Dar al-Salam li al-Nashr wa al-Tawzi`.

Al-Ghazali, A.H. (t.t.), Ihya' Ulum al-Din, juz. 4, Beirut: Dar al-Ma`rifah.

Al-Ghazali, A.H.M. (1990), Mukashafah al-Qulub, al-Haram: Matba`ah al-Irshad.

Al-Jurjani, 'A.M. (1985), Kitab al-Ta rifat. Beirut: Maktabah Lubnan.

Al-Kashani, 'A.R. (2007), Mu'jam Istilahat al-Sufiyyah, tahqiq `Abd al-Khaliq Mahmud, c. 3, Kaherah: Maktabah al-'Adab.

Al-Mu'jam al-'Arabi al-Asasi (t.t.), t.tp.: al-Munzamat al-'Arabiyyah li al-Tarbiyyah wa al-Thaqafah wa al-'Ulum.

Al-Mu'jam al-Wasit (t.t.), Ed. Majma' al-Lughat al-'Arabiyyah, cet. ke-3. t.tp.: Majma' al-Lughat al'Arabiyyah.

Al-Munjid fi al-Lughah wa al-A'lam (1988), Cet. ke-30. Beirut: Dar al-Mashriq, Ba`albaki, Munir (1991), al-Mawrid Qamus Inklizi-'Arabi, Beirut: Dar al-'Ilm li al-Malayin. 
INTERNATIONAL JOURNAL OF ACADEMIC RESEARCH IN BUSINESS AND SOCIAL SCIENCES

Vol. 8, No. 10, Oct. 2018, E-ISSN: 2222-6990 @ 2018 HRMARS

al-'Imad,(1989), Shadharat al-Dhahab fi Akhbar Man Dhahab, tahqiq Mahmud al-Arna'ut, juz. 5, Beirut: Dar Ibn Kathir.

Kathir, A.F.I. (1998), Al-Bidayah wa al-Nihayah, tahqiq `Abd Allah ibn `Abd al-Muhsin al-Turki, juz. 16, Giza: Markaz al-Buhuth wa al-Dirasat al-`Arabiyyah al-Islamiyyah.

Jeremy Pope (2007), Sistem Integriti Nasional Asas-asas Panduan. Institut Integriti Malaysia (trans.), Kuala Lumpur: Institut Integriti Malaysia (IIM).

Kamus Dewan (2007), fourth edition, Kuala Lumpur: Dewan Bahasa dan Pustaka.

Kamus Dwibahasa (2008), first edition, Petaling Jaya: Pearson Malaysia Sdn. Bhd.

Kamus Inggeris Melayu Dewan (2002), c. 3, Kuala Lumpur: Dewan Bahasa dan Pustaka.

Ismail, M. Z. \& Badron, M. S. (2011), Good Governance Adab-Oriented Tadbir in Islam, Kuala Lumpur: IKIM.

Ali, M. (2009), "Integriti dan Islam: Aplikasi Berkesan Membangun Ummah", dalam Institut Integriti Malaysia (ed.), Integriti Dan Islam: Aplikasi Berkesan Membangun Ummah, Kuala Lumpur: Institut Integriti Malaysia (IIM).

New Oxford (2004), Shah Alam: Oxford Fajar Sd. Bhd.

Al-Hakim, S. (1981), al-Mu `jam al-Sufi, Beirut: Dandarah li al-Tiba`ah wa al-Nashr.

Aziz, W. M. A. (2009), "Menyemai Benih Integriti Dalam Kalangan Masyarakat: Dasar Dan

Peraturan", in Institut Integriti Malaysia (ed.), Integriti Dan Islam: Aplikasi Berkesan Membangun

Ummah, Kuala Lumpur: Institut Integriti Malaysia (IIM).

al-Qaradawi,Y. (1994), al-Imam al-Ghazali bayn Madihi wa Naqidihi, c. 4, Beirut: Muassasah al-

Risalah.

Zulkifli, M. B. (2008), Integriti Dalam Islam, c. 2, Bandar Baru Nilai: Penerbit USIM.

Zulkifli , M. B. (2009), "Islam Dan Integriti: Konsep Ketauhidan Terhadap al-Khaliq", in Institut Integriti Malaysia (ed.), Integriti Dan Islam: Aplikasi Berkesan Membangun Ummah, Kuala Lumpur: Institut Integriti Malaysia (IIM).

Hamat, M. F. and Shuhari, M. H. (2017), "al-Ghazali's thought on Ethics of Living in the Society Based on Bidayah Al-Hidayah", International Journal of Academic Research in Business and Social Sciences, Vol. 7, No. 6, 846-857. 